\title{
A comparison of single-suture and double-suture incision closures in seaward-migrating juvenile Chinook salmon implanted with acoustic transmitters: implications for research in river basins containing hydropower structures
}

\author{
Richard S Brown ${ }^{1 *}$, Katherine A Deters ${ }^{1}$, Katrina V Cook $^{1}$ and M Brad Eppard ${ }^{2}$
}

\begin{abstract}
Background: Reductions in the size of acoustic transmitters implanted in migrating juvenile salmonids have resulted in the ability to make smaller incisions that may warrant using only a single suture for closure. However, it is not known if one suture will sufficiently hold the incision closed, particularly when outward pressure is placed on the surgical site, such as when migrating fish experience pressure changes associated with passage at hydroelectric dams. The objective of this research was to evaluate the effectiveness of single-suture incision closures on juvenile Chinook salmon (Oncorhynchus tshawytscha).

Results: Juvenile Chinook salmon were surgically implanted with a 2012 Juvenile Salmon Acoustic Telemetry System (JSATS) transmitter $(0.30 \mathrm{~g})$ and a passive integrated transponder tag $(0.10 \mathrm{~g})$, and incisions were closed with either one suture or two sutures. Mortality and tag retention were monitored, and tagged fish were examined after 7 and $14 \mathrm{~d}$ to evaluate tissue responses. In a separate experiment, surgically implanted fish were exposed to simulated turbine passage and then examined for expulsion of transmitters, expulsion of viscera through the incision and mortal injury. With incisions closed using a single suture, there was no mortality or tag loss and similar or reduced tissue reaction compared to incisions closed with two sutures. Furthermore, surgery time was significantly reduced when a single suture was used, which led to less handling time and time under anesthesia and consequently, stress. No tags were expelled during pressure scenarios. Expulsion of viscera occurred in two non-mortally injured fish (5\%) with single sutures that were exposed to very high pressure changes, but no viscera expulsion was present in fish exposed to pressure scenarios, likely representative of hydroturbine passage at many Columbia River dams (for example, $<2.7$ ratio of pressure change, acclimation pressure of 146.2 absolute $\mathrm{kPa}$ and lowest exposure pressure of about 53.3 absolute $\mathrm{kPa}$ ).
\end{abstract}

Conclusions: We recommend the use of a single suture for surgical implantation of transmitters with incisions that are approximately $5.5 \mathrm{~mm}$ long after tag insertion.

Keywords: Telemetry, Juvenile salmon, Sutures, Surgery, Hydropower, Barotrauma, Tag effects

\footnotetext{
* Correspondence: Rich.brown@pnnl.gov

${ }^{1}$ Pacific Northwest National Laboratory, Ecology Group, Post Office Box 999,

Richland, WA 99352, USA

Full list of author information is available at the end of the article
} 


\section{Background}

Within the U.S. Pacific Northwest, large numbers of juvenile salmonids are implanted with telemetry tags to monitor survival and migration behavior associated with passage through hydroelectric facilities [1,2]. Models used for these studies assume that these tagged individuals are representative of entire populations, and thus the accuracy of the resulting data is essential to managers and researchers. The presence of a telemetry tag and the tagging process (referred to as tag or tagging effects) have the potential to influence growth, behavior and survival of fish $[3,4]$. This creates a constant need for the improvement and advancement of technology and surgical techniques in an attempt to minimize tag effects and to allow tagging of smaller fish. An inability to monitor the smallest fish within a study population, such as seaward-migrating salmonid smolts, likely biases research results on these populations.

Recently, the reduction in the size of acoustic transmitters (for example, Advanced Telemetry Systems [Isanti, MN, USA] model SS160 weighs $0.3 \mathrm{~g}$ (in air), approximately $30 \%$ less mass than the previous 0.43 -g transmitter, $10.7 \times 5.0 \times 2.8 \mathrm{~mm}$ ) has resulted in the ability to make smaller incisions when surgically implanting transmitters. With a smaller incision, using fewer sutures for incision closure may be a viable option to improve surgical techniques and minimize the influence on tagged fish [5]. With shorter surgery times, fewer needle entry and exit points and less suture material in contact with the fish, a single-suture closure could minimize effects of anesthesia and handling. For example, following surgical implantation of passive integrated transponder (PIT) tags in Nile tilapia (Oreochromis niloticus), Baras et al. [6] found higher survival and faster healing but reduced retention of tags in fish for which no suture was used compared to using just a single suture. Sutures are used to prevent rejection of the tag and maintain tissue contact at incision edges, which accelerates healing [7]. However, sutures can also act as a medium for fungal growth, and, after granulation tissue closes incision wounds, the active process of encapsulation and expulsion of tags is more common in fish with severe inflammatory responses $[7,8]$. Therefore, if additional sutures are not required to ensure tag retention and tissue contact, their presence may slow down wound healing, cause mortality and increase overall stress for fish [9]. Before a reduction in the number of sutures can be implemented in field studies, researchers must be confident that tags will be retained, even when fish are exposed to dynamic river environments, such as when passing hydroelectric facilities.

There are essentially three main routes of passage through a hydroelectric facility for seaward-migrating juvenile salmonids: the spillway, the turbines or a juvenile bypass facility. Juvenile salmonids passing through turbines are subjected to rapid decompression that can result in potentially fatal barotrauma-related injuries, including swim bladder rupture, exophthalmia, and emboli in the gills or kidney $[10,11]$. When fish pass through hydroturbines, they are exposed to low pressures on the back side of the turbine blades [12], which leads to the expansion of the gas in the swim bladder $[13,14]$. Similarly, fish that pass through the spillway of dams experience pressure changes that cause the swim bladder to expand. Swim bladder expansion during rapid decompression can exert pressure on surgically implanted transmitters, which usually lie between the swim bladder and the incision. Therefore, fish bearing surgically implanted transmitters and subjected to turbine passage have the potential to expel their tags as well as viscera through the sutured incision [5]. If a tag is expelled, and so becomes stationary, the fish would be assumed to be dead, thus biasing survival estimates. An opened incision with protruding viscera could compromise the health of the fish by increasing its susceptibility to pathogens. Therefore, tagged fish with expelled viscera would not only have compromised health but also likely would not accurately represent untagged fish.

Previous research has been conducted to determine whether juvenile Chinook salmon implanted with a larger transmitter $(0.43 \mathrm{~g}, 12.0 \times 5.2 \times 3.8 \mathrm{~mm})$ would lead to tag expulsion if the incisions (6 to $8 \mathrm{~mm}$ long) were closed with a single suture [5]. Following exposure to simulated turbine passage, these researchers found no difference in tag retention, mortal injury (defined as mortality or injuries statistically associated with mortality [15]) or incision tearing between fish with incisions closed with one suture and those with two sutures. However, more fish with single-suture incision closures had expelled viscera compared to the fish with two sutures. Now that transmitters are smaller, incisions made for implanting transmitters can also be made smaller and fish may be less likely to expel viscera when incisions are closed using one suture.

The results from Boyd et al. [5] led to our investigation of the efficacy of a smaller incision length (5 to 6 $\mathrm{mm}$ ) and single-suture incision closure for surgical implantation of smaller acoustic transmitters (Juvenile Salmon Acoustic Telemetry System (JSATS) [2]). We compared survival, tag retention and incision healing among tagged fish sutured using one or two sutures. In addition, we exposed fish to pressure changes characteristic of turbine passage (see [16]) to determine whether tag and viscera expulsion were controlled when incisions of tagged fish were closed using a single suture.

\section{Results}

\section{4-day holding}

Over the course of the 14-d holding period, survival was high, no fish lost any sutures and no fish expelled their 
implanted transmitters or PIT tags. All single-sutured and control fish survived, but two (5\%) of the fish with two sutures died (10 and $11 \mathrm{~d}$ after surgery). However, there was no significant $(P=0.1521)$ difference in mortality between fish implanted using one or two sutures. Furthermore, it took significantly $(P<0.0001$; Figure 1$)$ less time for fish to be implanted with transmitters when using one suture (mean $=88 \mathrm{~s}$ ) compared to two sutures $($ mean $=122 \mathrm{~s})$. In both groups, mean incision lengths were $4.7 \mathrm{~mm}$ initially and $5.4 \mathrm{~mm}$ after tag insertion, indicating slight incision tearing during tag insertion.

There was no significant difference in growth (change in mass) between the single- and double-sutured fish either on day $7(P=0.725$; mean growth of $-0.4 \mathrm{~g}$ for double-sutured fish and $-0.4 \mathrm{~g}$ for single-sutured fish) or on day $14(P=0.846$; mean growth of $-0.5 \mathrm{~g}$ for doublesutured fish, $-0.5 \mathrm{~g}$ for single-sutured fish). Control fish had a mean growth of $-0.7 \mathrm{~g}$ and $-0.2 \mathrm{~g}$ following 7 and $14 \mathrm{~d}$ of holding, respectively.

There was no significant difference in redness between fish implanted using one suture and those implanted using two sutures when examined either $7 \mathrm{~d}(P=0.08)$ or $14 \mathrm{~d}$ $(P=0.10)$ after implantation (Figure 2$)$. The amount of redness was also not significantly associated with tag burden or incision length $7 \mathrm{~d}(P=0.34$ and $P=0.45$, respectively) or $14 \mathrm{~d}(P=0.33$ and $P=0.36$, respectively) after implantation.

Although there was no significant relationship between the number of sutures and ulceration $7 \mathrm{~d}$ after implantation $(P=0.10)$, there was significantly $(P=0.0151)$ more ulceration among fish with two sutures (mean $=4.9 \mathrm{~mm}^{2}$ ) than among those with one suture $\left(\right.$ mean $\left.=2.9 \mathrm{~mm}^{2}\right)$ after
$14 \mathrm{~d}$ (Figure 2). There was a significant positive relationship between tag burden and ulceration at $7 \mathrm{~d}(P=$ $0.0018)$ but not at $14 \mathrm{~d}(P=0.088)$ after implantation. Incision length had no effect on ulceration after $7 \mathrm{~d}(P=$ $0.18)$ or $14 \mathrm{~d}(P=0.63)$.

There was significantly more fungal load among fish that had two sutures than among those that had one suture at $7 \mathrm{~d}\left(P<0.0001,1.2 \mathrm{~mm}^{2}\right.$ and $2.7 \mathrm{~mm}^{2}$ for singlesuture and double-suture fish, respectively) and $14 \mathrm{~d}$ $\left(P<0.0001,2.2 \mathrm{~mm}^{2}\right.$ and $5.4 \mathrm{~mm}^{2}$ for single-suture and double-suture fish, respectively) postimplantation (Figure 2). There was no significant relationship between tag burden or incision length and the presence of fungus at $7 \mathrm{~d}(P=0.29$ and $P=0.26$, respectively) or $14 \mathrm{~d}(P=$ 0.95 and $P=0.79$, respectively) after implantation.

\section{Simulated turbine passage}

The occurrence of no tag expulsion, a low percentage of fish with visceral expulsion and a high probability of mortal injury among fish with viscera expulsion precluded the need for further statistical analyses. A total of 109 fish (54\% of exposed fish) were mortally injured. Viscera were expelled from the incisions of 15 fish (7.5\% of exposed fish). However, all of the fish with expelled viscera were exposed to higher than average ratios of pressure change. The mean ratio of pressure change for fish with viscera expulsion was 3.2 (range = 2.7 to 4.4$)$, and the mean nadir pressure was 6.9 psia (range $=4.8$ to 7.9 ) compared to 2.5 (1.4 to 4.4 ) and 9.0 psia (range $=4.8$ to 15.1 ), respectively, for fish without viscera expulsion.

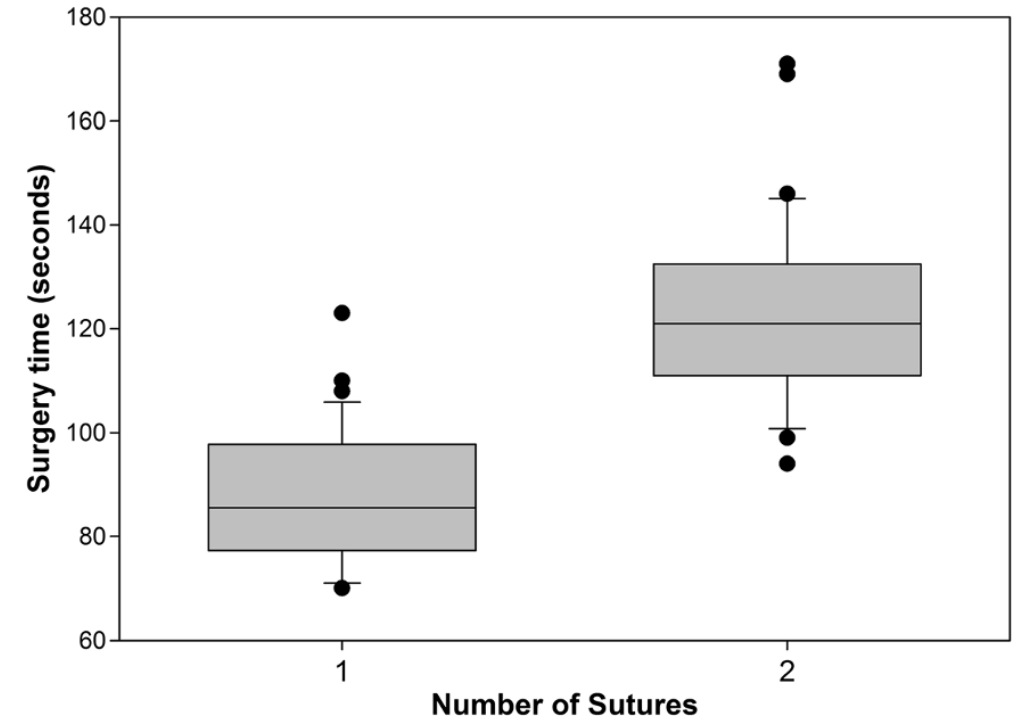

Figure 1 Boxplots of the amount of time it took to surgically implant acoustic transmitters in juvenile Chinook salmon using one or two sutures (line within box = median; lower edge of box $=25$ th percentile; upper edge of box $=75$ th percentile; ends of whiskers $=$ $1.5 \times$ interquartile range; points $=$ outliers) 


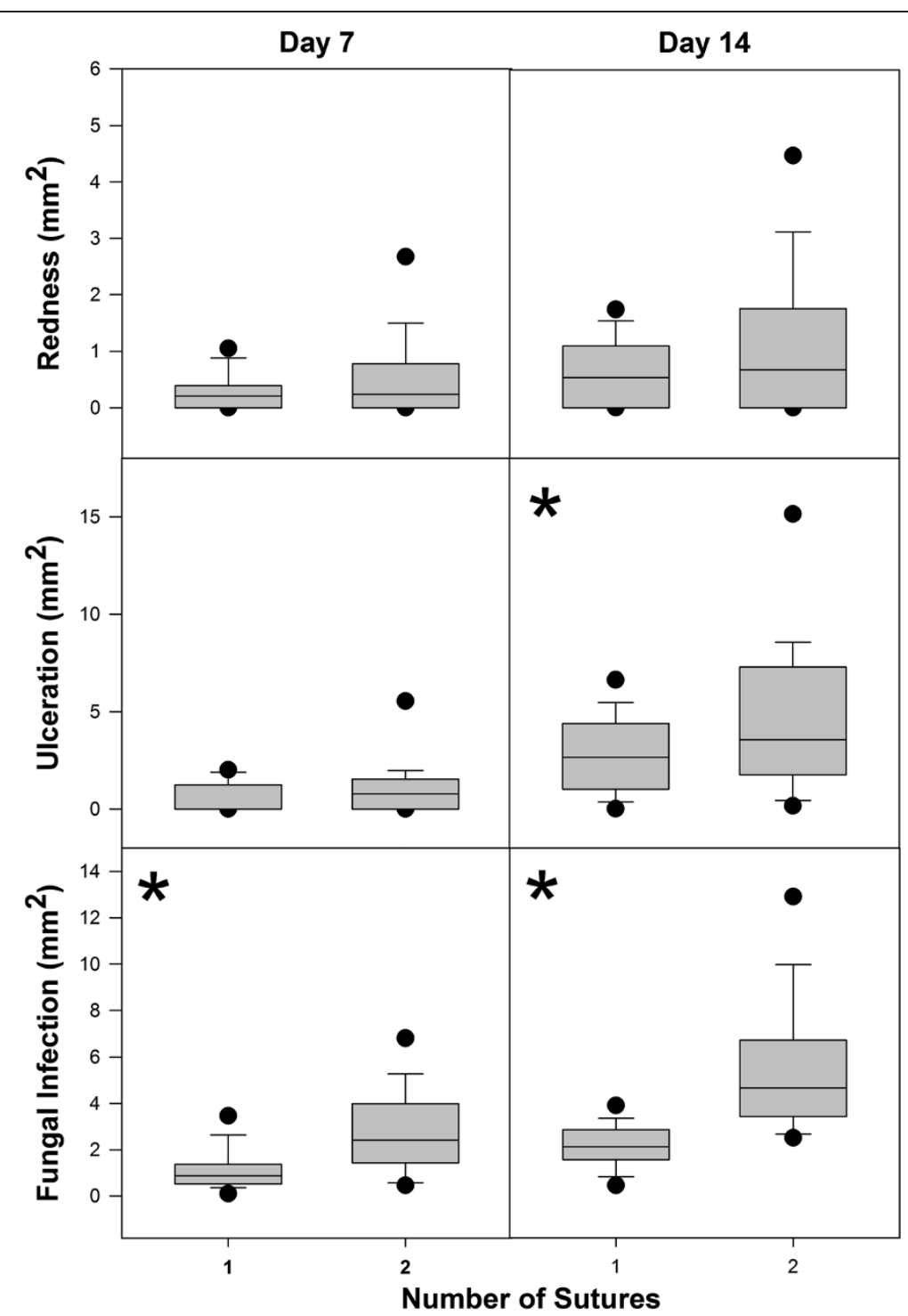

Figure 2 Boxplots of condition scores of juvenile Chinook salmon tagged with acoustic transmitters using either one or two sutures to close the incision $\mathbf{7}$ and $\mathbf{1 4} \mathbf{d}$ following surgery. Asterisks denote significant differences between groups (line within box = median, lower edge of box $=25$ th percentile, upper edge of box $=75$ th percentile, ends of whiskers $=1.5 \times$ interquartile range, points $=5$ th and 95th percentiles).

Most of the fish with expelled viscera were mortally injured. Of these 15 fish with expelled viscera, all but one (93\%) had a single suture closing the incision. Additionally, $87 \%$ of fish with viscera expulsion (12 with a single suture and 1 with double sutures) were mortally injured due to the pressure exposure. The two single-suture fish that were not mortally injured but had expelled viscera were exposed to ratios of pressure change of 2.9 and 2.7 , respectively.

\section{Discussion}

\section{4-d holding}

Tag retention, suture retention and tissue reaction metrics were either similar or better among fish tagged with a single suture versus double sutures. Fish with singlesuture incision closures had no tag loss and no suture loss, and the time to complete the surgery using one suture was nearly one-third the time for surgeries with two sutures. Thus, we would expect less tissue reaction and lower surgery times in future studies using one suture rather than two.

Although it might be assumed that fish tagged with a single suture would heal better than fish tagged with two sutures, previous studies have yielded mixed results. Deters et al. [17] compared the healing of fish tagged with one vs. two similar sutures as part of a broader study, but they did not find a difference between the two 
groups. Their study compared ulceration and redness up to $28 \mathrm{~d}$ after surgical implantation of similarly sized juvenile Chinook salmon (mean fork length [FL] 107 to $108 \mathrm{~mm}$ [range $=97$ to 120 ], mean weight 16.2 to $16.3 \mathrm{~g}$ [range $=10.6$ to 21.7]) with an acoustic transmitter. However, these fish were tagged using a different suturing technique (that is, four throws with two wraps each instead of the four throws with only one wrap knot used in this study) and with a larger transmitter $(0.43 \mathrm{~g}$ compared to $0.3 \mathrm{~g})$. The differences between these two studies (that is, Deters et al. [17] found no differences in ulceration between one-suture and two-suture fish on day 14) may have less to do with knot bulk and transmitter size and more to do with overall fish health. For instance, although the methods of measuring tissue reaction were the same between the two studies, in the present study, we report slightly higher mortality and much higher mean response levels, despite very similar techniques between the two studies, indicating that fish in this study could have been in poorer health.

\section{Simulated turbine passage}

Pressure changes rapidly when fish pass hydroturbines, and typically fish are exposed to pressures below surface pressure (with surface pressure at $101 \mathrm{kPa}$ ) [16]. The pressures fish experience can also change rapidly and to a great extent as fish are brought rapidly to surface, such as when passing spillways (especially spill from greater depths, termed "deep spill") or other water management structures (for example, irrigation weirs). The fact that none of the fish from the pressure treatments expelled their surgically implanted transmitter indicates that one suture may be effective in retaining implanted transmitters when fish are exposed to dynamic river environments.

Similar to our present work, Boyd et al. [5] also found that all acoustic transmitters surgically implanted into the body cavity of juvenile Chinook salmon using 6- to $8-\mathrm{mm}$ incisions and either one or two sutures were retained following exposure to ratios of pressure change ranging from 1.4 to 3.3 (acclimation to $146 \mathrm{kPa}$ ). Only $0.06 \%$ of juvenile Chinook salmon expelled acoustic transmitters surgically implanted into the body cavity using two sutures when exposed to ratios of pressure change ranging from 2.6 to 15.5 [16]. Brown et al. [10] found $2.4 \%$ to $2.8 \%$ of juvenile Chinook salmon gastrically implanted with radio transmitters expelled their transmitters when rapidly decompressed to ratios of pressure change ranging from 5.2 to 27.0. However, this is a much larger range of ratio pressure change; none of these fish expelled their radio transmitters when exposed to similar ratios of pressure change obtained in this study.

Despite a lack of tag expulsion, Boyd et al. [5] recommended that one suture is not appropriate to close 6to $8-\mathrm{mm}$ incisions in juvenile salmon due to a high percentage of viscera expulsion. Although all implanted tags were also retained in the present study, viscera were expelled in a small proportion (7.5\%) of fish exposed to rapid pressure change. However, unlike the Boyd et al. [5] study, most of these fish were mortally injured. Because it is highly probable that mortally injured fish will die during any studies of fish in dynamic river environments [11,15], viscera retention in these fish is not likely of concern.

Only two of the fish exposed to simulated turbine passage had expelled viscera and were not mortally injured; both of these fish had single-suture incision closures. An equation by Carlson et al. [18] used to relate rapid pressure change to mortal injury can be applied to determine the likelihood that these two fish would be mortally injured. Their equation requires the input of the tag burden and the natural log of the ratio of pressure change. The fish had a tag burden of 3.5\% and 3.8\% and were exposed to ratios of pressure change of 2.7 and 2.9 , respectively, or a natural $\log$ of the ratio of pressure change of 1.0 and 1.1. This would lead to a likelihood of mortal injury of about $64 \%$ for these two fish. These ratios of pressure change would cause the swim bladder to expand by 2.7 to 2.9 times upon rapid decompression. Swim bladders of juvenile Chinook salmon start to rupture, an injury predictive of mortality, when the pressure they are exposed to is cut in half (a ratio of pressure change of 2 [19]). Thus, it is not surprising that as the swim bladder expanded, viscera were expelled from the body cavity and these fish were characterized with a high probability of mortal injury.

To summarize, most (87\%) of the fish that expelled viscera were mortally injured. In addition, the two fish that expelled viscera but were not mortally injured would have a high likelihood of mortal injury if passing through a hydroturbine. Thus, it appears that fish likely to survive turbine passage are not likely to have increased visceral expulsion if their surgical incisions are closed with one suture instead of two sutures under the conditions used in this study (that is, $0.32 \mathrm{~g}$ JSATS transmitter and 5.5- $\mathrm{mm}$ incision after tag insertion).

\section{Conclusions}

On the basis of results obtained using juvenile Chinook salmon as a study species, we recommend the use of a single suture for surgical implantation of transmitters with incisions that are 5 to $6 \mathrm{~mm}$ long after tag insertion. This is based upon a lack of transmitter expulsion, a lack of a difference in growth and similar or reduced tissue reaction compared to incisions closed with two sutures. In addition, the reduced surgery time will likely lead to less handling and reduced stress when a single suture is used. However, these results may be speciesspecific, as the life history of some fish (for example, 
benthic species) may dictate a need for more sutures to prevent tag rejection.

Although expulsion of viscera was present in two non-mortally injured single-suture fish, no viscera expulsion was present in fish exposed to more mild ratios of pressure change that are likely representative of hydroturbine passage at many Columbia River dams [16]. Additionally, as hydroturbine passage is thought to be the most violent downstream passage route, we would expect further reduced mortality and viscera expulsion in fish passing by other routes, such as spillways or other water management structures. Still, research into pressure changes for fish exposed to deep spill is recommended.

The use of fewer sutures has to be balanced with the likelihood of tag loss and tissue expulsion when fish could be exposed to dynamic environments. We encourage further research to reduce the size of transmitters, which will likely lead to the ability to use smaller entries into the body cavity. In addition, smaller transmitters would lead to less bias in studies examining fish survival [18]. The use of smaller transmitters may also improve growth and viscera retention because the tag would take up less space in the body cavity.

\section{Methods}

Juvenile spring Chinook salmon were transported to the Aquatic Research Laboratory (ARL) at the Pacific Northwest National Laboratory as eyed eggs from the Leavenworth National Fish Hatchery. These fish were used for all aspects of this research as juveniles. All study fish were handled in accordance with federal guidelines for the care and use of laboratory animals, and experimental protocols (\#2011-26) were approved by the Institutional Animal Care and Use Committee, Battelle-Pacific Northwest Division.

The objectives of this study were met using a twopronged approach. First, we examined survival, tag retention, suture retention, tissue reaction and growth at 7 and $14 \mathrm{~d}$ postsurgery in single-suture and double-suture fish. Second, tag and organ retention were assessed after exposing fish of both suture types to simulated turbine passage.

\section{4-d holding \\ Surgical implantation}

Fish examined for this portion of the research consisted of three treatment groups with 40 fish for each treatment; 1 suture, 2 suture, and controls (no surgery). Test fish ranged in FL from 96 to $124 \mathrm{~mm}$ (mean $=107 \mathrm{~mm}$ ) and 10.5-24.1 g (mean $=15.8 \mathrm{~g})$ in weight (Table 1). Controls, not individually marked, were anaesthetized, weighed, and measured on surgery day, at day 7 and day 14. Transmitters used for surgical implantation were JSATS transmitters (model prototype SS160) that weighed $0.3 \mathrm{~g}$ in air and $0.19 \mathrm{~g}$ in water and had a volume of $0.11 \mathrm{ml}(10.7 \times 5.0 \times$ $2.8 \mathrm{~mm}$ ). PIT tags were also implanted to simulate field study conditions on the Snake and Columbia rivers. For in-river studies, PIT tags are implanted with acoustic transmitters to prevent fish from being sorted into transport barges or trucks at the juvenile fish facilities of hydroelectric dams. PIT tags (Destron Technologies, St. Paul, $\mathrm{MN}$, USA) were $12.5 \times 2.1 \mathrm{~mm}$, and $0.10 \mathrm{~g}$ in air and 0.06 $\mathrm{g}$ in water and had a volume of $0.04 \mathrm{ml}$. Tag burdens (ratio of transmitter mass to fish mass) ranged from $1.7 \%$ to $3.8 \%$ (mean $=2.6 \%$, Table 1$)$.

One surgeon performed all surgeries to eliminate surgeon bias [8]. All surgeries were performed on 11 November 2011. Anesthesia and surgical protocols were followed as outlined by Deters et al. [17] with some modifications. Prior to surgery, fish were weighed and measured. A 4- to 5-mm incision was made on the linea alba (similar to Panther et al. [20]) and measured with calipers to the nearest quarter of a millimeter. The incision was made slightly smaller than the width of the transmitter to allow the smallest incision necessary for each fish. A PIT tag and an acoustic transmitter were implanted through the incision, and the incision was measured again for any tearing. Monocryl absorbable 50 monofilament sutures (Monocryl; Ethicon, Somerville, NJ, USA) were used to close incisions with either one or two simple interrupted sutures tied with reinforced

Table 1 Sample size, mean length, mass and tag burdens (ratio of tag weight to body weight) of controls and treatments of juvenile Chinook salmon tagged with transmitters using either one or two sutures to close the incision ${ }^{\text {a }}$

\begin{tabular}{|c|c|c|c|c|}
\hline Treatment & $n$ & Mean length $(\mathrm{mm})$ & Mean mass (g) & Mean tag burden (\%) \\
\hline \multicolumn{5}{|l|}{ 14-d holding } \\
\hline Single-suture & 40 & 109 (99 to 124) & 16.5 (11.3 to 24.1$)$ & 2.5 (1.7 to 3.5$)$ \\
\hline Double-suture & 40 & 107 (96 to 120$)$ & 15.6 (10.5 to 22.9$)$ & 2.6 (1.7 to 3.8$)$ \\
\hline Control & 40 & 106 (96 to 115$)$ & 15.1 (10.7 to 20.4$)$ & \\
\hline \multicolumn{5}{|c|}{ Simulated turbine passage } \\
\hline Single-suture & 100 & 103 (95 to 116$)$ & 13.1 (9.0 to 18.6$)$ & 3.1 (2.2 to 4.4$)$ \\
\hline Double-suture & 101 & 103 (95 to 117$)$ & $13.0(8.8$ to 17.9$)$ & $3.1(2.2$ to 4.5$)$ \\
\hline
\end{tabular}

Tagged fish were also exposed to simulated turbine passage. 
square knots ([17]; Figure 3). Knots were made with one wrap on each of four throws.

\section{Assessment of tissue reaction}

Surgeries were timed and recorded for each fish, and photographs of the incisions were taken for comparison of tissue reaction and fungal load at 7 and $14 \mathrm{~d}$ postsurgery. Test fish were allowed to recover from anesthesia and placed in a 490- $\mathrm{L}$ circular tank inside the $\mathrm{ARL}$, where they were held at approximately $17^{\circ} \mathrm{C}$ for 14 d. Lights inside the ARL were controlled to follow the natural photoperiod, and fish were fed daily ad libitum (Bio-Oregon, Salem, OR, USA).

At $7 \mathrm{~d}$ postsurgery, fish were anesthetized in an 80 $\mathrm{mg} / \mathrm{L}$ solution of tricaine methanesulfonate (MS-222) buffered with sodium bicarbonate. All fish were weighed, and the incisions of treatment fish were photographed and graded according to four parameters: suture retention, redness, ulceration and fungal load (similar to Deters et al. [17]). Imaging software (Image-Pro; Media Cybernetics, Inc., Rockville, MD, USA) was used to measure the surface area (in $\mathrm{mm}^{2}$ ) of affected tissue when redness, ulceration or fungus was present. Fish were then allowed to recover from anesthesia and returned to the holding tank until the process was repeated at $14 \mathrm{~d}$ postsurgery. Mortality and tag loss were also monitored daily throughout the holding period.

\section{Statistics}

To examine differences in tissue responses between treatments after 7 and $14 \mathrm{~d}$, a multivariate analysis of variance model was created for each time period with three response variables (redness, ulceration and fungus) and five explanatory variables (fish weight, tag burden,

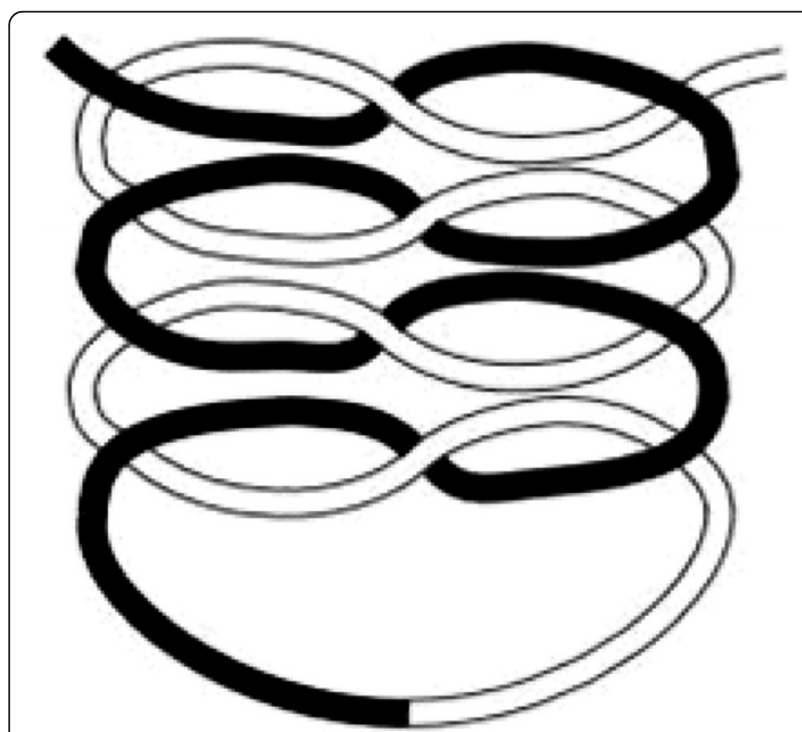

Figure 3 Illustration of a $1 \times 1 \times 1 \times 1$ reinforced surgeon's knot incision length, surgery time and number of sutures; there was no tag or suture loss in this study). All response variables were continuous. Correlation matrices revealed fish weight and tag burden, as well as surgery time and number of sutures, to be highly correlated. Therefore, surgery time and fish weight were removed from further analyses. None of the response variables were correlated. Growth was calculated at the individual level for marked treatment fish but overall (for example, mean mass at time 2 subtracted by mean mass at time 1) for unmarked controls. Differences in surgery time and growth between suture types were determined using $t$-tests. Differences in mortality between suture types were tested using a $\chi^{2}$ test.

\section{Simulated turbine passage \\ Surgical implantation}

Surgeries on the 201 juvenile Chinook salmon exposed to simulated turbine passage were performed as described in the previous sections, but the time it took for each surgery was not recorded. Test fish were similar in size to the previous experiment, ranging from 95 to 117 $\mathrm{mm}$ FL (mean $=103 \mathrm{~mm}$ ) and 8.8 to $18.6 \mathrm{~g}$ in weight $($ mean $=13.1 \mathrm{~g}$; Table 1$)$. Tag burdens ranged from $2.2 \%$ to $4.5 \%$ (mean $=3.1 \%$; Table 1$)$. During each surgery day (from 26 October to 21 November 2011), a total of 32 fish were surgically implanted with tags, 16 of which had incisions closed with a single suture and the remaining 16 with two sutures. After surgery, fish were weighed and measured, fin-clipped for individual identification and placed into perforated floating buckets in groups of eight: four single-suture fish and four double-suture fish per bucket. The four buckets of eight fish were held in a 490-L holding tank for approximately $24 \mathrm{~h}$.

\section{Acclimation and exposure}

Following the 24-h recovery period, each bucket of eight fish was transferred to one of four hyper/- hypobaric chambers (detailed in Stephenson et al. [19]). All fish were acclimated to a pressure of $146.2 \mathrm{kPa}$ (4.6 m water depth equivalent) for approximately $20 \mathrm{~h}$. As salmonids are physostomous fish without an active rete, they fill their swim bladders by gulping atmospheric air. As such, study fish had access to a bubble of air at the top of the chamber throughout acclimation to attain neutral buoyancy. After the acclimation period, each fish was visually assessed using methods described by Pflugrath et al. [14] to determine whether it had achieved neutral buoyancy. Fish that were not neutrally buoyant were omitted from further study.

Fish were exposed to pressure profiles designed to simulate passage through a turbine intake, approach the turbine runner, travel out of the turbine draft tube and into the tailrace, and finally travel up to the water 
surface ending at atmospheric pressure [19]. Nadir pressures, the lowest exposure pressure, ranged from 33.1 to $104.1 \mathrm{kPa}$. According to Boyle's law, the volume of a gas is inversely proportionate to the pressure acting on the volume [21]. Therefore, for a fish passing through infrastructure, if the surrounding pressure is decreased by half, the volume of the preexisting gas, such as that inside the swim bladder, in the body doubles. An easy way to understand the effect of pressure change on fish while accounting for acclimation pressure is to refer to the ratio of pressure change. This refers to the pressure at which fish were acclimated divided by the nadir pressure. The ratio of pressure change is equal to the magnitude of swim bladder expansion during rapid decompression. Consequently, this expanding swim bladder could push against the transmitter and the surgical incision.

\section{Necropsy}

After a 10-min observation period, fish were anesthetized with an $80 \mathrm{mg} / \mathrm{L}$ dose of MS-222 and photographs of incisions were taken. Observations were made to determine whether there was any incision tearing, organs protruding or tag loss. Fish were then allowed to recover for an 8-h holding period to monitor survival and immediate tag retention before being euthanized and necropsied.

Necropsies were performed on all euthanized fish to determine whether any injuries were sustained during simulated turbine passage exposure. Four researchers who were experienced in necropsy techniques and procedures performed all necropsies. Necropsy procedures included external examination for emphysema and emboli. Fish were also examined internally for ruptured swim bladders, hemorrhages and other damage to the organs. Using these data, the presence of mortal injury as characterized by McKinstry et al. [15], as well as tag retention, was assessed.

\section{Abbreviations}

ARL: Aquatic Research Laboratory; FL: Fork length; JSATS: Juvenile Salmon acoustic telemetry system; MS-222: Tricaine methanesulfonate; PIT: Passive integrated transponder.

\section{Competing interests}

The authors declare that they have no competing interests.

\author{
Authors' contributions \\ RSB and KAD designed prepared and executed the experiments of this \\ study. RSB analyzed the data and drafted the manuscript. KAD collected the \\ data and assisted with drafting the manuscript. KVC assisted with \\ interpretation of results and drafting of the manuscript. MBE conceived of \\ the study and helped with study design and funding. All authors read and \\ approved the final manuscript.
}

\section{Authors' information}

RSB and KAD are scientists at the Pacific Northwest National Laboratory. KVC is a research associate at the Pacific Northwest National Laboratory. MBE is a fish biologist for the U.S. Army Corps of Engineers, Portland District.

\section{Acknowledgements}

Funding for the research described in this report was provided by the U.S. Army Corps of Engineers, Portland District. The authors thank John Skalski and Adam Seaburg of the University of Washington for scientific and statistical advice. Jill Janak, Andrea Currie, Andy LeBarge, Tim Linley, Amanda OToole, John Stephenson and Ricardo Walker of the Pacific Northwest National Laboratory provided valuable assistance. Animal facilities were certified by the Association for Assessment and Accreditation of Laboratory Animal Care. Fish were handled in accordance with federal guidelines for the care and use of laboratory animals, and protocols were approved by the Institutional Animal Care and Use Committee, Battelle-Pacific Northwest Division. Reference to trade names does not imply endorsement by Battelle or the U.S. government.

\section{Author details}

'Pacific Northwest National Laboratory, Ecology Group, Post Office Box 999, Richland, WA 99352, USA. ${ }^{2}$ U.S. Army Corps of Engineers, Portland District, 333 Southwest First Avenue, Portland, Oregon 97204, USA.

Received: 13 February 2013 Accepted: 24 May 2013

Published: 15 July 2013

\section{References}

1. Hockersmith EE, Muir WD, Smith SG, Sandford BP, Perry RW, Adams NS, Rondorf DW: Comparison of migration rate and survival between radio-tagged and PIT-tagged migrant yearling Chinook salmon in the Snake and Columbia rivers. N Am J Fish Manag 2003, 23:404-413.

2. MCMichael GA, Eppard MB, Carlson TJ, Carter JA, Ebberts BD, Brown RS, Weiland M, Ploskey GR, Harnish RA, Deng ZD: The juvenile salmon acoustic telemetry system: a new tool. Fisheries 2010, 35:9-22.

3. Adams NS, Rondorf DW, Evans SD, Kelly JE: Effects of surgically and gastrically implanted radio transmitters on growth and feeding behavior of juvenile Chinook salmon. Trans Am Fish Soc 1998, 127:128-136.

4. Brown RS, Harnish RA, Carter KM, Boyd JW, Deters KA, Eppard MB: An evaluation of the maximum tag burden for implantation of acoustic transmitters in juvenile Chinook salmon. N Am J Fish Manag 2010, 30:499-505.

5. Boyd JW, Deters KA, Brown RS, Eppard MB: Efficacy of single-suture incision closures in tagged juvenile Chinook salmon exposed to simulated turbine passage. Trans Am Fish Soc 2011, 140:1186-1192.

6. Baras E, Westerloppe L, Mélard C, Philippart JC, Bénech V: Evaluation of implantation procedures for PIT-tagging juvenile Nile tilapia. N Am J Aquac 1999, 61:246-251.

7. Ivasauskas TJ, Bettoli PW, Holt T: Effects of suture material and ultrasonic transmitter size on survival, growth, wound healing and tag expulsion in rainbow trout. Trans Am Fish Soc 2012, 141:100-106.

8. Deters KA, Brown RS, Carter KM, Boyd JM, Eppard MB, Seaburg AG: Performance assessment of suture type, water temperature, and surgeon skill in juvenile Chinook salmon surgically implanted with acoustic transmitters. Trans Am Fish Soc 2010, 139:888-899.

9. Jepson N, Koed A, Thorstad EB, Baras E: Surgical implantation of telemetry transmitters in fish: how much have we learned? Hydrobiologia 2002, 483:239-248.

10. Brown RS, Carlson TJ, Welch AE, Stephenson JR, Abernethy CS, Ebberts BD, Langeslay MJ, Ahmann ML, Feil DH, Skalksi JR, Townsend RL: Assessment of barotrauma from rapid decompression of depth-acclimated juvenile Chinook salmon bearing radiotelemetry transmitters. Trans Am Fish Soc 2009, 138:1285-1301.

11. Brown RS, Carlson TJ, Gingerich AJ, Stephenson JR, Pflugrath BD, Welch AE, Langeslay MJ, Ahmann ML, Johnson RL, Skalski JR, Seaburg AG, Townsend RL: Quantifying mortal injury of juvenile Chinook salmon exposed to simulated hydro-turbine passage. Trans Am Fish Soc 2012, 141:147-157.

12. Deng ZD, Carlson TJ, Duncan JP, Richmond MC, Dauble DD: Use of an autonomous sensor to evaluate the biological performance of the advanced turbine at Wanapum Dam. J Renew Sust Energ 2010, 2:053104

13. Brown RS, Pflugrath BD, Colotelo AH, Brauner CJ, Carlson TJ, Deng ZD: Pathways of barotrauma in juvenile salmonids exposed to simulated hydroturbine passage: Boyles law vs. Henry's law. Fish Res 2012, 121:43-50. 
14. Pflugrath BD, Brown RS, Carlson TJ: Maximum acclimation depth of juvenile Chinook salmon: implications for survival during hydroturbine passage. Trans Am Fish Soc 2012, 141:520-525.

15. McKinstry CA, Carlson TJ, Brown RS: Derivation of mortal injury metric for studies of rapid decompression of depth-acclimated physostomous fish (Tech. Rep. PNNL-17080). Richland, WA: Pacific Northwest National Laboratory; 2007.

16. Carlson TJ, Duncan JP, Deng ZD: Data overview for sensor fish samples acquired at Ice Harbor, John Day, and Bonneville II dams in 2005, 2006, and 2007 (Tech. Rep. PNNL-17398). Richland, WA: Pacific Northwest National Laboratory; 2008.

17. Deters KA, Brown RS, Boyd JW, Eppard MB, Seaburg AG: Optimal suturing technique and number of sutures for surgical implantation of acoustic transmitters in juvenile salmonids. Trans Am Fish Soc 2012, 141:1-10.

18. Carlson TJ, Brown RS, Stephenson JR, Pflugrath BD, Colotelo AH, Gingerich AJ, Benjamin PL, Langeslay M, Ahmann ML, Johnson RL, Skalski JR, Seaburg A, Townsend RL: The influence of tag presence on the mortality of juvenile Chinook salmon exposed to simulated hydroturbine passage: implications for survival estimates and management of hydroelectric facilities. N Am J Fish Manag 2012, 32:249-261.

19. Stephenson JR, Gingerich AJ, Brown RS, Pflugrath BD, Deng ZD, Carlson TJ, Langeslay M, Ahmann ML, Johnson RL, Seaburg AG: Assessing barotrauma in neutrally and negatively buoyant juvenile salmonids exposed to simulated hydro-turbine passage using a mobile aquatic barotrauma laboratory. Fish Res 2010, 106:271-278.

20. Panther JL, Brown RS, Gaulke G, Deters KA, Woodley CM, Eppard MB: Influence of incision location on transmitter loss, healing, survival, growth, and suture retention of juvenile Chinook salmon. Trans Am Fish Soc 2011, 140:1492-1503.

21. Van Heuvelen A: Physics: a general introduction. Boston: Little, Brown \& Co.; 1982.

doi:10.1186/2050-3385-1-10

Cite this article as: Brown et al:: A comparison of single-suture and double-suture incision closures in seaward-migrating juvenile Chinook salmon implanted with acoustic transmitters: implications for research in river basins containing hydropower structures. Animal Biotelemetry 2013 1:10.

\section{Submit your next manuscript to BioMed Central and take full advantage of:}

- Convenient online submission

- Thorough peer review

- No space constraints or color figure charges

- Immediate publication on acceptance

- Inclusion in PubMed, CAS, Scopus and Google Scholar

- Research which is freely available for redistribution 